Volume 3 Issue 1 (2019) Pages 274 - 282

Jurnal Obsesi : Jurnal Pendidikan Anak Usia Dini

DOI: $10.31004 /$ obsesi.v3i1.160

\title{
The Problem Solving Skills in Kindergarten Student Based on the Stages of Problem Solving
}

\author{
Anung Driyas Maraning Dyah ${ }^{1}$, Farida Agus Setiawati ${ }^{2}$ \\ Early Childhood Education, Graduate School Program, Yogyakarta State University
}

\begin{abstract}
The direct involvement of parents and teachers frequently appear in the problem solving which is faced by early childhood. Therefore, there are some problems that actually can be solved by children. This research aims to describe the level of children's skill in solving the daily problem based on the problem solving thinking process. This research involve 25 children as participant in the range of age 4-6 years old in the Pertiwi Tumanggal Kindergarten. The collection of data was conducted by using interview technique. The data of children's problem solving skill were quantitatively analysed. From the finding, it is obtained some results such as: (1) the most problem solving skill of children in Pertiwi Tumanggal Kindergarten is in medium category; (2) some items of statement which are still low are the reason to select the appropriate solution and the conviction in selecting the solutions.
\end{abstract}

Keywords: problem solving, early childhood, age of 4-6 years old,

\begin{abstract}
Abstrak
Keterlibatan langsung orang tua dan guru sering muncul dalam pemecahan masalah yang dihadapi oleh anak usia dini. Oleh karena itu, ada beberapa masalah yang sebenarnya bisa diselesaikan oleh anak sendiri. Penelitian ini bertujuan untuk mendeskripsikan tingkat kemampuan anak dalam memecahkan masalah sehari-hari berdasarkan proses berpikir pemecahan masalah. Penelitian ini melibatkan 25 anak sebagai peserta dalam kisaran usia 4-6 tahun di TK Pertiwi Tumanggal. Pengumpulan data dilakukan dengan menggunakan teknik wawancara. Data tingkat kemampuan pemecahan masalah anak-anak dianalisis secara kuantitatif. Dari temuan tersebut, diperoleh beberapa hasil seperti: (1) kemampuan memecahkan masalah anak-anak di TK Pertiwi Tumanggal berada dalam kategori sedang; (2) beberapa item pernyataan yang masih rendah adalah alasan untuk memilih solusi yang tepat dan keyakinan dalam memilih solusi.
\end{abstract}

Kata Kunci : pemecahan masalah, anak usia dini, usia 4-6 tahun

@ Jurnal Obsesi Prodi PG-PAUD FIP UPTT 2019

$\triangle$ Corresponding author :

Address : Jl. Colombo No.1, Karang Malang

Email : anungdriyas26@gmail.com

ISSN 2356-1327 (Media Cetak)

ISSN 2549-8959 (Media Online) 


\section{INTRODUCTION}

Early childhood education is an education service as a basic potency for children to optimally grow and develop (Pangastuti, 2014: 8; Partini, 2010). In this stage, the development of children is rapidly developed in whole aspects: physical, psychology, social, or spiritual, and also being sensitive to the stimulation received by children from the environment (Pangastuti, 2014: 8). This thing is based on the Constitution of Republic of Indonesia Number 20 Year 2003 about National Education System article 1 item 14 which states that: "Early childhood education is a guiding effort which is addressed to children from they born until they are six years old which is conducted through the giving of educational stimulation to help the physical and mental development to make sure that children poses the availability in entering the higher level of education".

All abilities possessed by children since their early age are important to be understood and developed (Adams, 2006: 18). One of the important ability to the future of children is cognitive skill. Cognitive skill consists of 3 thinking areas, such as: learning and problem solving, logical thinking, and symbolical thinking (Suminah, Nugraha, Yusuf, \& Puspita, 2015). Most of researchers research cognitive skill through counting activity. The cognitive skill as mentioned in the previous explanation such as a research conducted by Ayuni \& Setiawati (2018) which observe the development of Kebun Buah (fruit garden) media to improve children's counting skill. Another study was conducted by Nurhayati \& Rasyid (2019) about the recognition of numbers through the outdoor game. Those researches only concern on the numerical cognitive skill. Therefore, the problem solving skill is also important to be researched and developed from early childhood. It is appropriate with the opinion from Karatas \& Baki (2013) which states that problem solving can be considered as an important life skill which involves various processes including analysing, interpreting, reasoning, predicting, evaluating, and reflecting.

Problem solving skill is not only used by adult, but it is also essential to create the basic of children's problem solving skill in their growth and development phase. Sulasamono (2012) also states that problem solving skill is resulted in a learning process which is an important learning result in education.

Problem solving skill for early childhood is very essential to be possessed because when children can solve problems, they can create the ability to think logically, critically, and systematically (Syaodih, Setiasih, Romadona, \& Handayani, 2018). Izzaty (2010) adds in her research that there are three reasons about the importance of problem solving skill for early childhood, those reason are: (1) influencing the function of self-adjustment in facing the conflict; (2) Doing positive and continual repetition to form those competences; and (3) positive problem solving which possibly influence the relationship with friends. The problems faced by children should be immediately solved or responded. In many cases, adults often getting involved and solve the problem that actually should be solved by their children. However, whatever problems faced by children even only small thing can be an opportunity for children to develop their problem solving skill (Brown, 1988).

Problem or conflict which can be faced by children is different with the problem faced by adults (Shadiq, 2009: 4; Utami, Utami, \& Sarumpaet, 2017). According to Dewey, problem is all confusing things, and challenging human's mind, and also making the conviction 
becomes vague (McLennan, 2012). The problem experience which is often faced by children especially at school, such as: snatching toys with friends, being difficult when learning new thing or new game, and the others (Shadiq, 2009:4; Utami, dkk, 2017).

The learning theory by Jean Piaget (Morrison, 2016: 239; Santrock, 2007: 243) is related with the cognitive development which explains about how children think deeply and make a concept about their knowledge including the problem solving matter. By considering the opinion from another figure such as Vygotsky who states that the cognitive skill of children is supported and developed through social interaction, not only children as the developer of their intelligence kecerdasannya sendiri (Morrison, 2016: 253). When children find the answer based on their own questions, so the related cognitive structure is continuously developed (Ünal \& Aral, 2014). The role of teacher and parent is to direct their attention to explain and teach the problem solving skill in the twentieth century (Kaya, Tadeu, SAHRANÇ, Arslan, \& Demir, 2017).

The ability in solving the problems is an opportunity in finding solution for a problem. It is in line with the opinion of George Polya (1973) a father of problem solving, In his book entitled How To Solve It states that problem solving is an effort to find the way out of the problems faced by individuals. A creative child with high curiosity, and the daily experiences which gives opportunity to solve the problems. When children realize that the problems of daily life can be simply solved with some ways (Ünal \& Aral, 2014).

A research by McLennan (2012) found that by using arts in solving the problems which can be regularly done, can help children to be long life thinker. According to Bingham, children with problem solving skill see how children with problem solving skill utilize the opportunity they have, find out different solution to solve difficulties they face, and make prediction about something. Children maintain their interest and attention to certain topic for the long period, they also notice the detail and realize their mistakes (McLennan, 2012).

Children should have opportunity to solve their problem alone and obtain experiences by their own idea. It is appropriate with Standar Pencapaian Perkembangan Anak (STTPA) or Children's Development Achievement Standard in the Regulation of Minister of Education and Culture Year 2014 Number 14 appendix 1 which explains that children in the age of 46 years old are expected to solve the simple problems in their daily life by themselves. Therefore, children are also accompanied with information when they solve daily problems which they have. The opportunity to solve problems encouraging children to create new mental relationship through communication with their environment. Children who are finding alternative solution actively use their brain (McLennan, 2012).

Another research shows that children obtain problem solving skill which starts from pre-school period and experiment based education program can be implemented to improve children's problem solving skill (Ünal \& Aral, 2014).

The traditional problem solving strategy has been taught to children which uses step by step action plan including understanding problems, making potential plan to solve the problem, execute the plan, and reflecting problems and realizing the plans they have. Despite this process gives a model which can be beneficial for children, it does not consider the full uncertainty in a situation which combines various perspectives, emotions, and 
experiences of children. İman (2013) also states that the method used by children in solving the problems is more important than by really facing the problems.

Specially, this research was conducted to cognize children's skill in solving simple problem from their daily life by using picture as a learning media.

\section{METHOD}

The research in this article is a kind of descriptive research, it emans that the research was conducted to describe a condition in an environment. It is in line with opinion by Arifin (2012: 140) which states that a descriptive research is a research used to describe and answer the discussion related to the phenomena that occur, whether in single variable, correlation, or comparison of every model. The method in this research was quantitatively analysed to see how big the problem solving skill of children. This analysis was also conducted qualitatively to explain the results of every indicator which assigned children's problem solving skill.

Children who participate in this research is divided into group $A\left(\mathrm{~N}_{\mathrm{a}}=12\right)$ dan group $B\left(N_{b}=13\right)$ at Pertiwi Tumanggal Kindergarten, Purbalingga. The 4-6 years old children join this interview activity at least for 3-5 minutes.

The data presented in this article is a result of observation through the interview with children to see their response in solving the problems. The problem in this article is presented by using simulation of pictures which describes common problems faced by children in their daily life in home or school, which is mainly about crash with friends. The collection of the data was helped by recording tool to make sure that children's answer is clearly heard. Children are asked to see the problems which occur in the picture and see whether the children have experienced those things and also ask children to give solution to the problem they face. Some open questions are used as an instrument to obtain the response of children related to the problem which can be seen in the figure 1 .

Those questions are not formally asked to children, but by using languages which is simply understood by children (Keller-hamela, 2007). Furthermore, the result of the interview is analysed based on the guidance of scoring which has been made which is calculated based on the total score obtained. The placement of score obtained is based on the answers of children.

1. What kind of problem which occurs in the picture?

2. Why that problem appears?

3. What solution which can be given related to the problem such as in the picture?

4. Which solutions that you choose?

5. Why do you choose that solution to solve the problem?

6. Are you sure with that solution?

7. How do you practice the selected solution?

8. What is the benefit from the solution that you choose?

Figure 1. The open question Related to the response of children.

The results of interview are the responses from children which are collected to cognize the level of problem solving skill. The interview was conducted in children's spare time which was about 3-5 minutes in shift. It is conducted to see children's natural response to avoid the response of the same answers. The agreement from students and teacher is also available to the purpose of this research. In the finding, we discuss about the data which were collected from the interview. 


\section{RESULT AND DISCUSSION}

Based on the research conducted in December 2018, it is known that children's response related to problem solving skill through the using of picture to solve the problems faced by children as seen in the table 1 below.

\section{Table 1. Recapitulation of calculation result of problem solving skill}

\begin{tabular}{|l|r|r|}
\hline \multicolumn{1}{|c|}{ Category } & N & Percentage \\
\hline Low & 9 & $36 \%$ \\
\hline Medium & 11 & $44 \%$ \\
\hline High & 5 & $20 \%$ \\
\hline
\end{tabular}

Based on table 1 above, it can be seen that the result of problem solving skill of children on high category only reaches 20 $\%$. That result is the whole result of children in the school. However, the achievement between group A and group B can be seen in the figure 2. Based on the figure 2 below, it can be seen that the result of identification to see and compare children's problem solving skill between group A and group B which is not significantly different.

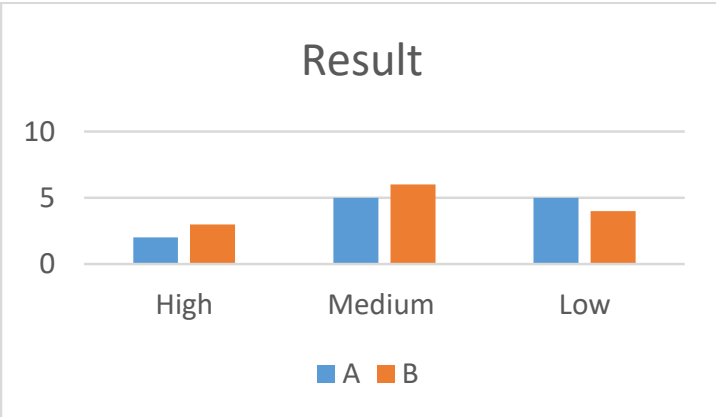

Figure 2. The Comparison of percentage result of children's problem solving skill calculation

The result of each criterion of children's problem solving skill is generally presented in every stage of problem solving which can be solved in the questions of interview as shown in the table at appendix
1 and appendix 2. Based on the table 1 in appendix 1 , the information of children's problem solving skill is obtained in 4-6 years old children in the medium criterion.

Based on table in appendix 1, some information which are obtained show the criterion of every question in each group at Pertiwi Tumanggal Kindergarten. In group $\mathrm{A}$, it is obtained that the result on question 1 about understanding the problem, children are in high category (67\%), question 2 about the cause of the problem which is in medium category (46\%), question 3 about mentioning solutions which can be used to solve the problem, are in medium category (46\%), question 4 about selecting solution which is in medium category (42\%), question 5 about giving the reasons in selecting solution which is in low category (21\%), question 6 about convincing that solution which is in low category (31\%), question 7 about practicing solution which is in medium category ( $46 \%$ ), and question 8 about the benefit of solution selected which is in low category (38\%).

In group $B$, it is obtained the result from question 1 about understanding the problem, children are in medium category (62\%), question 2 about the cause of the problem which is in medium category (50\%), question 3 about solutions which can be used to solve the problem, are in medium category (58\%), question 4 about selecting solution which is in medium category (35\%), question 5 about giving reasons to choose that solution which is in medium category (35\%), question 6 about convincing that solution which is in low category $(31 \%)$, question 7 about practicing solution which is in medium category (58\%), and question 8 about the benefit of solution selected which is in medium category (38\%). Every child in unique. It means that, every child has different ability between one child to another child or the children who have 
special characteristics in their development. One important ability which should be possessed by children is problem solving skill in the daily life.

Problem solving skill is very essential to early childhood. It is in line with opinion from Ismail, Ismail, \& Aun (2015) which states that children without problem solving skill in their early childhood will tend to be more aggressive to other people and finally tend to agree with social problem such as friends' refugee, being involved in crime and having mental problems when they are adult.

\section{Recognizing Problem Content}

The skill of children in recognizing and understanding the problems which is more understood by children. More than a half of the group, children can express the problem they face. Based on the figure shown about children who are fighting, children can understand that children in the picture have problems, such as fighting, quarrelling, and others which describe the act of children who want to fight with the others. Besides that, some children can tell that many of their friends do the same. From those answers, children seem that children are able to cognize a problem that they may face in their daily life.

\section{Revealing the Source of the Problem}

Children's ability in revealing the cause of the problem is the sequence of recognizing problem content Kemampuan anak untuk dapat mengung-kapkan. Averagely, the ability of children is in medium category in this indicator. Some children can reveal the cause of quarrelling occurred, and some of them are unable. Children think that why they get involved in a fight because they snatch the toys, it starts unconsciously until being a real fight among them. Some children did not know the real cause of the problem.

\section{Planning the Solution}

Planning solution stage in problem solving is the further step from identifying the problem, such as recognizing the content of problem and understanding the cause of problem. Based on the result obtained, it is concluded that averagely children in planning the solution is in medium category. It is shown by the ability of children in giving at least 1 solution to solve the problem they face. In the fighting problem that children usually face, children give one or more solutions such as: reporting to teacher, separating the children who are fighting, asking friends to forgive each other, etc. Although in the same category, group B has bigger percentage than group $\mathrm{A}$, it is because children in group B are braver to give response to the problem faced by other children.

\section{Selecting the Solution}

In the stage of selecting the solution, it is in medium category. It can be seen from the fact that children tend to report the problem to their teacher other than to solve the problem independently by themselves. This result also is also obtained because children only can make 1 solution which causes there is no option to choose solutions.

\section{The Reason in Selecting the Solution}

To reveal the reason why that solution still be used to solve the problems, group A is in low category and group $\mathrm{B}$ is in medium category. Children in group $\mathrm{A}$ are unable to think about the decent reason why they use that solution. Children tell their ignorance about the reason for the solution that they choose. 


\section{Convincing the Solution}

In this stage where children are optimistic in their solution that they choose, both group A and group B are in the low category. It can be seen from the children that are still hesitated about the solution that they made. Children are still worried about their solution, it means that children are still afraid of the consequences that possibly occur.

\section{Practicing the Solution}

In the stage of practicing solution, children are in medium category. It means that, children can directly try to practice the solution that they choose. For example, children choose to report to teacher when there are other children fight by saying some sentences such as "Teacher, they are fighting", "Teacher, she is crying because somebody disturbs her", etc. Or, children choose to separate children who are fighting by asking them to apologize. Some expression which are used by children such as "hey, don't punch your friend", “don't fighting", and others.

\section{Understanding the Benefit of Solution}

The last stage is understanding benefit from solution that children choose. The result obtained by both group A and group $\mathrm{B}$ is in medium category. Children utter that fight against friends is not good and also to finish the problems quickly and there is no child who cries because hurts.

\section{CONCLUSION}

Based on the result of children's problem solving skill, some conclusions can be concluded as follow: (1) the most problem solving skill of children in Pertiwi Tumanggal Kindergarten is in medium category; (2) some items of question which are still low are the reason to select the appropriate solution and conviction in selecting the solutions. The question item which has the highest score is the ability of children to recognize problems. Otherwise, the question item which has the lowest score is the ability to give a reason to choose the solution.

\section{ACKNOWLEDGEMENT}

Many thanks to Yogyakarta State University especially Graduate School Program which had helped and supported so this article is accomplished. Many thanks also to my thesis supervisor, Farida Agus Setiawati, who had guided me in finishing this article. The last, I also dedicate this article to my parents and others who had helped and motivated me in accomplishing this article.

\section{REFERENCES}

Adams, K. (2006). Semua Anak Jenius: Aktivitas Seru untuk Mengembangkan Kecerdasan Anak Usia 0-11 Tahun. Jakarta: Erlangga.

Arifin, Z. (2012). Penelitian Pendidikan Metode dan Paradigma Baru. Bandung: Rosda Karya.

Ayuni, D., \& Setiawati, F. A. (2018). "Kebun Buah" Learning Media for Early Childhood Counting Ability. Jurnal Obsesi : Jurnal Pendidikan Anak Usia Dini, 2(1), 85-93. https://doi.org/10.31004/obsesi.v3i1.1 28

Brown, L. J. (1988). Helping Children Learn To Solve Problems. DAY CARE AND EARLY EDUCATION, 26-30.

İman, E. D. (2013). The Social ProblemSolving Questionnaire : Evaluation of Psychometric Properties Among Turkish Primary School Students. Eurasian Journal of Educational Research, (52), 97-116.

Ismail, N., Ismail, K., \& Aun, N. S. M. (2015). The role of scaffolding in 
problem solving skills among children. In International Proceedings of Economics Development and Research (Vol. 85, pp. 89-100). Singapore: IACSIT Press.

Izzaty, R. E. (2010). Pemecahan Masalah Sosial sebagai Faktor dalam Pendidikan Karakter Anak Usia Dini. Jurnal Psikologi, 6(2), 156-170.

Karatas, I., \& Baki, A. (2013). The Effect of Learning Environments Based on Problem Solving on Students' Achievements of Problem Solving. International Electronic Journal of Elementary Education, 5(3), 249267.

https://doi.org/10.12973/nefmed201

Kaya, M., Tadeu, P., SAHRANÇ, Ü., Arslan, S., \& Demir, S. (2017). An Investigation of Problem Solving Skills in Preschool Education. Sakarya University Journal of Education, 7(3), 506-514. https://doi.org/10.19126/suje.315715

Keller-hamela, M. (2007). The Child Interview . Practice Guidelines 1 . Rapport building and developmental assessment. Organization for Security and Co-Operation in Europe, 1-9.

McLennan, D. M. P. (2012). Using Sociodrama to Help Young Children Problem Solve. Early Childhood Education Journal. https://doi.org/10.1007/s10643-0110482-9

Morrison, G. S. (2016). Pendidikan Anak Usia Dini Saat Ini. Yogyakarta: Pustaka Pelajar.

Nurhayati, F., \& Rasyid, H. (2019). Implementation of Outdoor Games to Improve 4-5 Year Old Children' $\mathrm{s}$ Number Sense. Jurnal Obsesi : Jurnal Pendidikan Anak Usia Dini, 3(1), 915.

https://doi.org/10.31004/obsesi.v3i1.1 33

Pangastuti, R. (2014). Edutainment Pendidikan Anak Usia Dini.
Yogyakarta: Pustaka Pelajar.

Partini. (2010). Pengantar Pendidikan Anak Usia Dini. Yogyakarta: Grafindo Litera Media.

Polya, G. (1973). How To Solve It (2nd ed.). Princeton: Princeton University Press.

Santrock, J. W. (2007). Perkembangan Anak. Jakarta: Erlangga.

Shadiq, F. (2009). Kemahiran Matematika. Yogyakarta: PPPPTK Matematika.

Sulasamono, B. S. (2012). PROBLEM SOLVING: Signifikansi, Pengertian, dan Ragamnya. Satya Widya, 28(2), 155-166.

Suminah, E., Nugraha, A., Yusuf, F., \& Puspita, W. A. (2015). Kerangka Dasar dan Struktur Kurikulum 2013 Pendidikan Anak Usia Dini. Jakarta: Direktorat Pembinaan Pendidikan Anak Usia Dini Direktorat Jenderal Pendidikan Anak Usia Dini dan Pendidikan Masyarakat Kementerian Pendidikan dan Kebudayaan.

Syaodih, E., Setiasih, O., Romadona, N. F., \& Handayani, H. (2018). Pengembangan Kemampuan Pemecahan Anak Usia Dini dalam Pembelajaran Proyek di Taman Kanak-kanak. Jurnal Pendidikan Usia Dini, 12(1), 29-36. https://doi.org/10.21009/JPUD.12103

Ünal, M., \& Aral, N. (2014). An Investigation on the Effects of Experiment Based Education Program on Six Years Olds' Problem Solving Skills '. Education and Science, 39(176), 279-291. https://doi.org/10.15390/EB.2014.359 2

Utami, L. O., Utami, I. S., \& Sarumpaet, N. (2017). Penerapan Metode Problem Solving dalam Mengembangkan Kemampuan Kognitif Anak Usia Dini melalui Kegiatan Bermain. Tunas Siliwangi, 3(2), 175-180. 
282 | The Problem Solving Skills in Kindergarten Student Based

\section{APPENDIX}

Appendix 1. The Total of Scores Based on Each Question

\begin{tabular}{|c|c|c|c|c|c|c|c|c|c|}
\hline \multicolumn{2}{|c|}{\begin{tabular}{c} 
Kelompok \\
\cline { 2 - 10 }
\end{tabular}} & $\mathbf{1}$ & $\mathbf{2}$ & $\mathbf{3}$ & $\mathbf{4}$ & $\mathbf{5}$ & $\mathbf{6}$ & $\mathbf{7}$ & $\mathbf{8}$ \\
\hline \multirow{4}{*}{ A } & $\begin{array}{c}\text { Total } \\
\text { Score }\end{array}$ & 16 & 11 & 11 & 10 & 5 & 6 & 11 & 9 \\
\cline { 2 - 11 } & $\%$ & $(67 \%)$ & $(46 \%)$ & $(46 \%)$ & $(42 \%)$ & $(21 \%)$ & $(31 \%)$ & $(46 \%)$ & $(38 \%)$ \\
\cline { 2 - 11 } & Category & High & Medium & Medium & Medium & Medium & Medium & Medium & Medium \\
\hline \multirow{3}{*}{ B } & $\begin{array}{c}\text { Total } \\
\text { Score }\end{array}$ & 16 & 13 & 15 & 9 & 9 & 8 & 15 & 10 \\
\cline { 2 - 11 } & $\%$ & $(62 \%)$ & $(50 \%)$ & $(58 \%)$ & $(35 \%)$ & $(35 \%)$ & $(31 \%)$ & $(58 \%)$ & $(38 \%)$ \\
\cline { 2 - 11 } & Category & Medium & Medium & Medium & Medium & Medium & Medium & Medium & Medium \\
\hline \multicolumn{2}{|c|}{ Average } & $65 \%$ & $48 \%$ & $52 \%$ & $39 \%$ & $28 \%$ & $31 \%$ & $52 \%$ & $38 \%$ \\
\hline
\end{tabular}

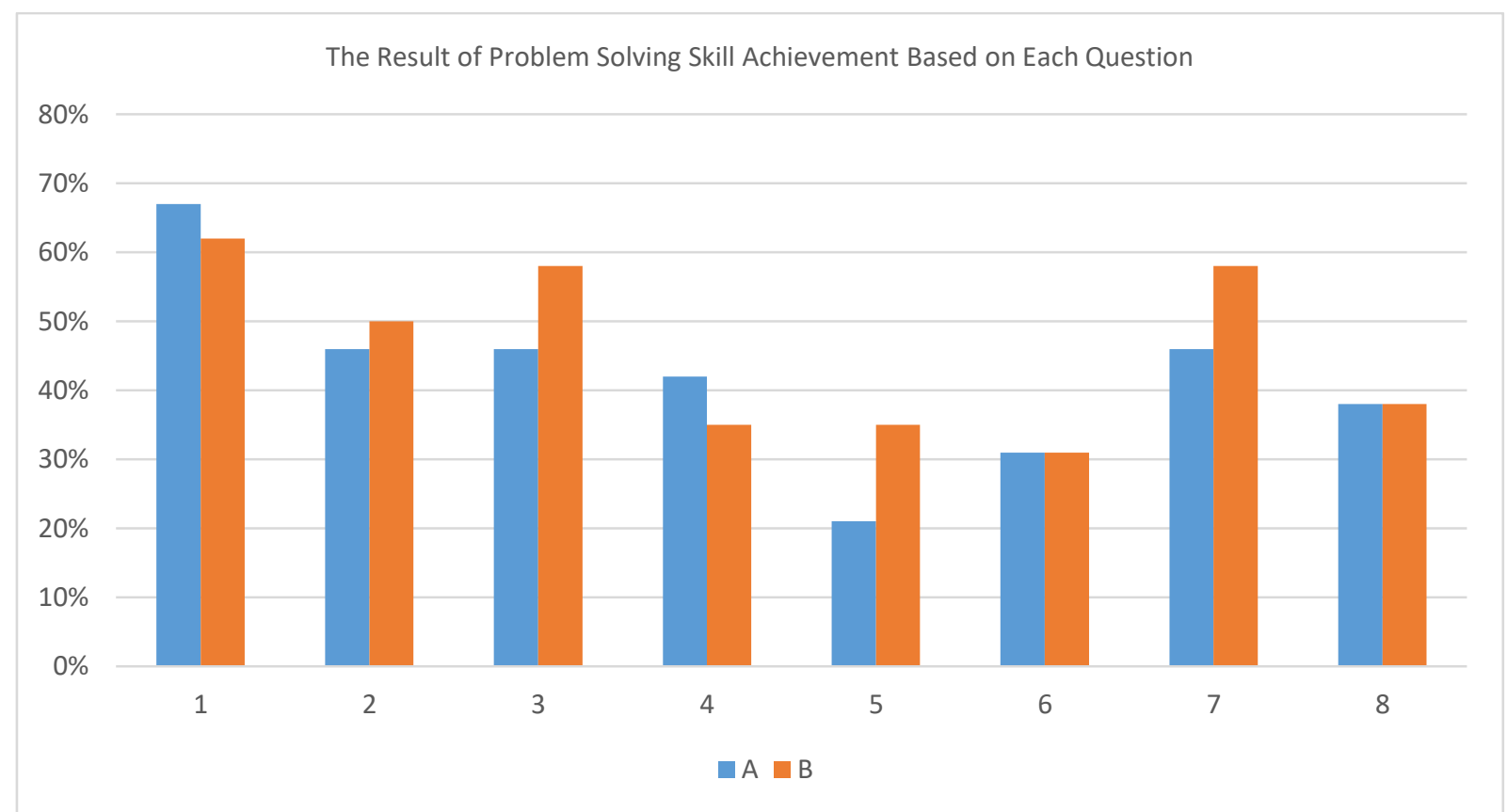

Appendix 2. Graphic of the Comparison of Percentage Result of Problem Solving Skill for Each Question 